\title{
Iberia in 1816, the year without a summer
}

\author{
Ricardo M. Trigo, ${ }^{\mathrm{a}, \mathrm{b} *}$ José M. Vaquero, ${ }^{\mathrm{c}}$ Maria-João Alcoforado, ${ }^{\mathrm{d}}$ Mariano Barriendos, ${ }^{\mathrm{e}}$ \\ João Taborda, ${ }^{\mathrm{f}}$ Ricardo García-Herrera ${ }^{\mathrm{g}}$ and Juerg Luterbacher ${ }^{\mathrm{h}}, \mathrm{i}$ \\ a Centro de Geofísica da Universidade de Lisboa, Lisbon, Portugal \\ b Departamento de Engineering Civil da Universidade Lusófona, Lisbon, Portugal \\ c Departamento de Física Aplicada, Escuela Politécnica, Universidad de Extremadura, Avda. de la Universidad s/n, 10071 Cáceres, Spain \\ d Centro de Estudos Geográficos, Universidade de Lisboa, Portugal \\ e Departamento de Historia Moderna, Universidad de Barcelona, Spain \\ ${ }^{\mathrm{f}}$ Escola Secundária Gabriel Pereira, Évora, Portugal \\ g Dto. Física de la Tierra II, Facultad de Físicas, Universidad Complutense, Spain \\ ${ }^{\mathrm{h}}$ Oeschger Centre for Climate Change Research and National Centre of Competence in Research on Climate (NCCR), University of Bern, Bern, \\ Switzerland \\ ${ }^{\mathrm{i}}$ Institute of Geography, Climatology and Meteorology, University of Bern, Bern, Switzerland
}

\begin{abstract}
The year 1816 was characterized by unusual weather conditions, in particular, by a cold and wet summer season ('year without a summer') on both the European and North American continents. The eruption of Tambora, an active stratavolcano, on the Island of Sumbaya (Indonesia) in April 1815 has been identified as the main driving force for the strong 1816 temperature anomaly. This climate anomaly has been relatively well studied in central Europe, France, Scandinavia and the United Kingdom. The unusual unsettled weather and climate at mid-latitudes in 1816 and 1817 had major socioeconomic impacts, particularly in terms of a poor yield of agricultural production, malnutrition and consequentially an increased potential for diseases and epidemics. The Iberian Peninsula was also affected by the intense climate anomalies during those years. Documentary sources describe the impact that the cold and wet summer of 1816 had on agriculture, namely the bad quality of fruits, delayed ripening of vineyards and cereals.

It is within this context that we stress the relevance of recently recovered meteorological observed data, from 1816 onwards, for stations located in Portugal (Lisbon) and also for a longer period for the Spanish stations of Madrid, Barcelona and San Fernando-Cadiz. We have compared observed (station-based) and large-scale reconstructed seasonal temperature anomalies computed for the winter and summer seasons after the eruption (1816-1818). There is qualitative agreement between the two independent data sets, though some stations partly indicate stronger departures from the long-term averages for single years compared to neighbouring grid points. In particular, all available stations reveal a cold summer of 1816 , mainly in July and August. In comparison to the 1871-1900 reference period, those two months were $2-3{ }^{\circ} \mathrm{C}$ cooler, close to what has been reported for central Europe. We also discuss the regional climate anomalies for those years (1816-1818) using independently reconstructed atmospheric circulation fields. Copyright (c) 2008 Royal Meteorological Society
\end{abstract}

KEY WORDS Tambora; Iberian Peninsula; cold summer; climate anomalies; climate impacts

Received 29 March 2007; Revised 9 January 2008; Accepted 15 January 2008

\section{Introduction}

It is known that the year 1816 was characterized by unusual weather on a global scale. In particular, parts of Europe and North America experienced a wet and cold summer season ('year without a summer' e.g. Stommel and Stommel, 1983; Stothers, 1984; Briffa and Jones, 1992; Harington, 1992; Robock, 1994; Lamb, 1995; Piervitali et al., 1997; Stothers, 1999; Mann et al., 2000). On the basis of a mixture of observed and proxy data, temperature reconstructions have highlighted the summer of 1816 as one of the coldest summers in the Northern Hemispheric (NH) scale (Briffa et al., 1998, 2004; Mann et al., 2000), in particular for areas of Europe (e.g.

\footnotetext{
* Correspondence to: Ricardo M. Trigo, Centro de Geofísica da Universidade de Lisboa, Departamento de Física, Faculdade de Ciências, Campo Grande, Ed C8, Piso 6, 1749-016 Lisbon, Portugal.

E-mail: rmtrigo@fc.ul.pt
}

Pfister, 1995; Chuine et al., 2004; Luterbacher et al., 2004; Guiot et al., 2005; Le Roy Ladurie, 2005; Menzel, 2005; Büntgen et al., 2006, 2008; Le Roy Ladurie et al., 2006; Diodato, 2007; Meier et al., 2007).

The catastrophic eruption of Tambora, on the Island of Sumbaya (Indonesia), in April 1815 (e.g. Sigurdsson and Carey, 1992) was almost certainly the main driving force for the strong 1816 climatic anomaly. Two major tropical eruptions and probably a third one occurring in a so far unidentified location (Figure 1) (e.g. Bruzek, 1992; Bradley and Jones, 1995, Chenoweth, 2001). All these previous works confirm that Tambora's eruption was, most probably, the largest in modern historical times, with the largest value of Volcanic Explosivity Index (VEI) recorded (7) supported by new independent proxy evidence (ratio between the measured red-to-green ratios of a few hundred paintings and the dust veil index) Zerefos et al. (2007). 


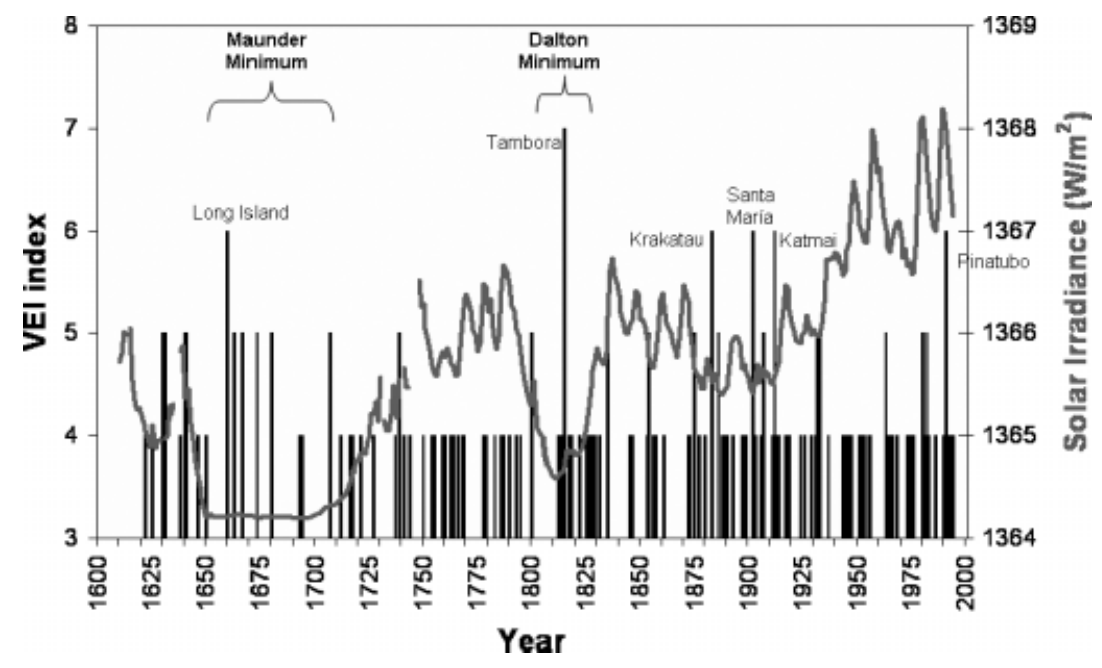

Figure 1. Solar irradiance reconstruction by Lean et al. (1995) and VEI index during the last four centuries. Data from www.volcano.si.edu (Simkin and Siebert, 1994).

For a comprehensive assessment on the impact of large volcanic eruptions on Earth/European climate, readers may consult Robock (2000); Robock and Oppenheimer (2003); Pisek and Brázdil (2006); Fischer et al. (2007 and references therein) and Zerefos et al. (2007).

These eruptions occurred during the so-called Dalton minimum of solar activity (1790-1830) when several important climate forcings changed markedly relative to previous times (e.g. Lean et al., 1995; Mann et al., 1998; Stendel et al., 2005; Wagner and Zorita, 2005). Apart from several strong volcanic eruptions, that period is also well known as a period characterized by reduced sunspot numbers (Hoyt and Schatten, 1998; Vaquero, 2007) and lower solar irradiance (e.g. Lean et al., 1995; Mann et al., 1998; Stendel et al., 2005; Wagner and Zorita, 2005). In summary, both external climate forcing factors, acting at different temporal scales, were responsible for the unusual cool climate anomaly in the early 19th century (Figure 1).

Independently from the relative weight of all contributing factors, the unusual weather at mid-latitudes in the decade between 1811 and 1820 had major socioeconomic impacts, particularly in terms of poor yield of agricultural production, malnutrition and consequentially an increased potential for diseases and epidemics in Europe and the Mediterranean countries (e.g. Lamb, 1970; Post, 1970; Harington, 1992; Lamb, 1995; Xoplaki et al., 2001; Webb, 2002; Brönnimann, 2003; Le Roy Ladurie, 2004; Pisek and Brázdil, 2006 and references therein).

Meteorological observations performed at standard hours and with relatively well-calibrated instruments had just become a routine procedure at the end of the 18th century, particularly in the United Kingdom and central and western Europe (Jones et al., 1999; Slonosky et al., 2001), northern Italy (Camuffo, 2002; Maugeri et al., 2002) and Scandinavia (Bergström and Moberg, 2002). However, the study of climate in both Iberian countries (Portugal and Spain) in the early 19th century has been hampered because of the following peculiarities: Firstly, the difficult socio-political context of the times, with large socio-economic unrest triggered by the Napoleonic wars and amplified by internal political conflicts, particularly by the independence movements of the South American colonies. In this respect, there was no particular sensitivity towards this climatic/environmental anomaly. Secondly, unlike other European countries, studies aiming to reconstruct the climatic situation on the basis of documentary evidence are relatively scarce, implying that the information available is more limited (e.g. Luterbacher et al., 2006 for a review). Thus, information from Iberia for this period mostly comes from a few natural proxies or from several reconstructions of gridded temperature fields at the monthly/seasonal scales over the continents for the last centuries (e.g. Briffa and Schweingruber, 1995; Briffa et al., 2001, 2004; Mann, 2002; Luterbacher et al., 2004; Guiot et al., 2005; Xoplaki et al., 2005). This inevitably decreases the quality of these reconstructions for the Iberian Peninsula (e.g. Briffa and Schweingruber, 1995; Luterbacher et al., 2006). The existence of relatively few tree-ring reconstructions and the absence of ice cores or coral proxies for Iberia do not facilitate a full characterization of the 1816 climate in this region, even when the application of more robust techniques to multiproxy data can improve reconstruction skill scores over that area (e.g. Briffa et al., 2004; Luterbacher et al., 2004; Pauling et al., 2006 and Xoplaki et al., 2005).

It is within the context previously described, that we underline the relevance of using recently recovered meteorological observations from 1816 onwards, for three stations located in Portugal (Lisbon, Coimbra and Oporto) and also for a longer period for the Spanish stations of Madrid, Barcelona and San Fernando-Cadiz, close to Gibraltar (Figure 2). This recently re-discovered data will allow a better characterization of the anomalous climate for this peculiar period over south-western Europe. Therefore, the main objectives of this article are as follows: 


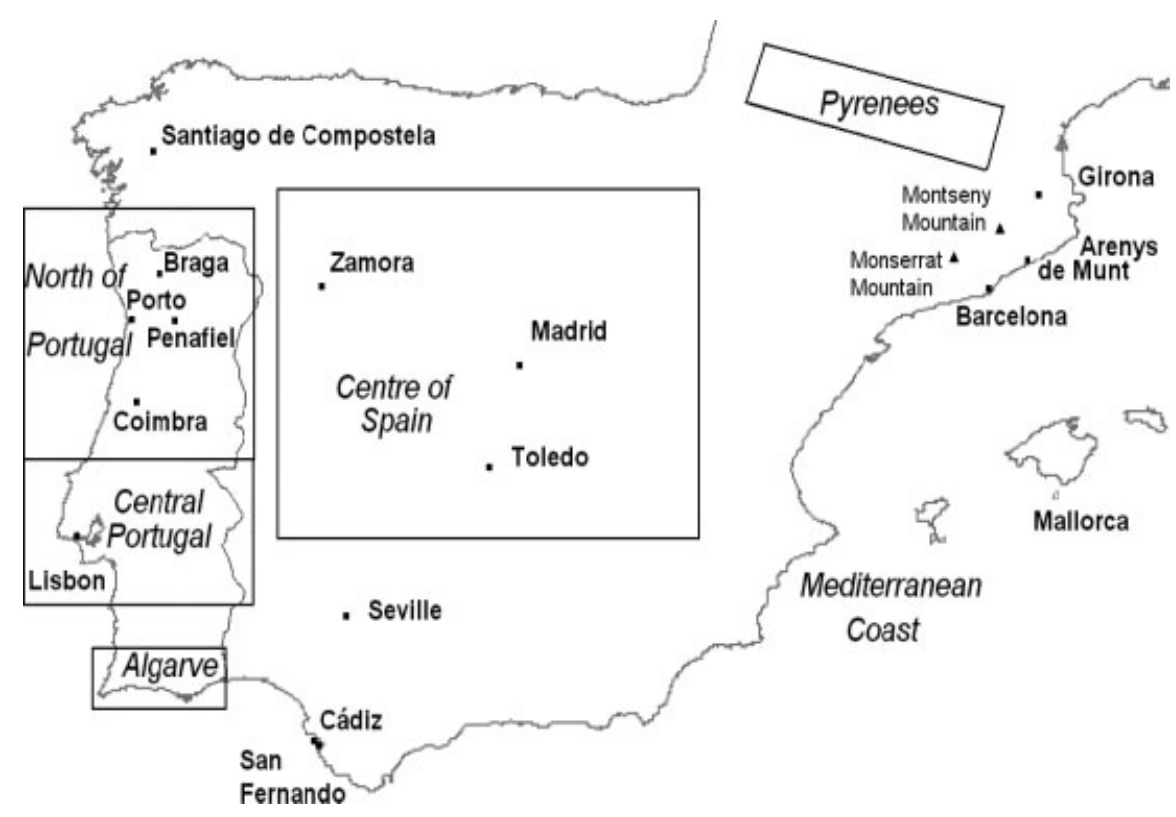

Figure 2. The location of all sites with relevant sources of documentary and/or station data, with small triangles (boxes) used for identifying specific mountains (large regions) mentioned in this work.

1. To characterize some of the impacts in the Iberian Peninsula during the period 1816-1817, particularly those related with agriculture production yields.

2. To assess the climate over Iberia (temperature and precipitation) during the short period that spans between 1816 and 1820 and compare it with the 1871-1900 period unaffected by global warming.

3. To compare seasonal anomalies of temperatures obtained with the early instrumental data for selected stations over Iberia and corresponding high-resolution reconstructed fields (temperature and sea-level pressure) recently developed.

Using documentary sources, Section 2 provides a qualitative assessment of the impact of anomalous weather in Iberia, during the years between 1816 and 1817. Metadata information on the re-discovered time series is provided in Section 3 and the corresponding analysis on the anomalous climate observed in Lisbon, Madrid, Barcelona, Cádiz and San Fernando is given in Section 4. Results are interpreted in Section 5, both in terms of reconstructed temperature and related atmospheric circulation using large-scale sea level pressure (SLP) information. Finally discussions and conclusions are provided in Section 6.

\section{Socio-economic impact of intense climate fluctuations}

\subsection{Overview}

Unusual weather and large climate fluctuations are bound to have some influence on populations that are directly affected. Impacts can be of short (e.g. floods and heatwaves) or prolonged (e.g. droughts) duration. The vast majority of documents consulted in Portugal and Spain, concerning the peculiar weather events in 1816 and 1817 , have highlighted the direct impact of unusual temperature and precipitation regimes in crop yields and, secondly, in human (and animal) health. According to Xoplaki et al. (2001) the main factors controlling the growth and development of crops in the Mediterranean basin are those associated with seasonal patterns of temperature, humidity, precipitation, soil moisture and solar radiation. Therefore, these factors will impact on the size and quality of the harvest that, on certain occasions, can trigger episodes of hunger and famine, or even epidemics. Further, climatic instability during the agricultural growing season would contribute significantly to an unstable economic environment as described by Stothers (1984) through limited resources and rising prices of foodstuffs.

Most of the Iberian Peninsula is characterized by a Mediterranean climate, with the bulk of precipitation occurring during the wet (and cold) half of the years, i.e. between October and April (Trigo et al., 2004). Lack of water in winter and spring will be reflected on the crop yield. However, too much water in winter can be harmful by drowning the seeds and retarding root development (Xoplaki et al., 2001). A dry and sunny summer can be even beneficial for winter crops as long as the soil has sufficient reserves of soil moisture (that is dependent on the occurrence of significant precipitation in April and May). Unusual cold can do damage to crops, particularly the appearance of severe frost in spring, during the sensitive flowering stages (Bourke, 1984).

A relatively large number of written sources in Iberia refer to economical and social impacts of abnormal meteorological conditions that have occurred in 1816. Most of these sources correspond to personal recollections on the impact of the unusual atmospheric conditions, particularly in what concerns agricultural crops but also on public health. The spatial location of all these sources is 
depicted in Figure 2, with larger boxes identifying relatively homogeneous large geographic regions mentioned by some of these historical sources.

\subsection{Relevant information from documentary sources in Portugal}

In the northern part of the country, the 1816 summer was cold and rainy. José Manuel da Silva Tedim, priest and lawyer in Braga, has written that 'July of 1816 was a particularly unusual month concerning both rainfall and temperature. I am 78 years old and I have never seen so much rain and cold, not even in winter months [...]'. Later he states that '[...] the vineyard harvest lasted until the $19^{\text {th }}$ of November, due to the lack of heat necessary to mature grapes' (Marques, 2002). Almeida (1817) confirms the bad quality of olive production in December in Penafiel (north of the country), owing to the lack of heat and unusual high nebulosity during the 1816 summer. The same author gives very precise information concerning the weather in 1816: 'July had only three clear days and its highest temperature was $77^{\circ} \mathrm{F}\left(25^{\circ} \mathrm{C}\right)$, that is 8 degrees $\left(4.4^{\circ} \mathrm{C}\right)$ less than in 1814, according to my thermometrical measurements, which I have kept; furthermore July was also more humid [than 1814]. In August only 10 days were clear, and its highest temperature was $79^{\circ} \mathrm{F}\left(26.1^{\circ} \mathrm{C}\right)$ [...]; in September 7 days were clear, its highest temperature was $78.5^{\circ} \mathrm{F}\left(25.8^{\circ} \mathrm{C}\right), 1.5^{\circ} \mathrm{F}\left(0.8^{\circ} \mathrm{C}\right)$ less than in 1814'.

According to Almeida (1817), in Penafiel, the months of February, March and April 1817 had positive temperature anomalies, when compared to previous years, particularly to 1816 . It will be shown later that late winter and early spring of 1817 were indeed particularly warm over different regions of Iberia. Almeida stated that the high temperatures had delayed the dates of olive ripening, which only took place in April 1817. The same delay was observed in olive trees near Coimbra.

In central Portugal, several references were found concerning the occurrence of 'winter-like diseases' during the summer of 1816, mostly respiratory ones (Durão, 1817). Concerning agriculture, people complained about the bad quality of fruits, because of the too cool summer. 'The unusual cool weather in summer had evil consequences on fruit, that was unpleasant to taste. Grapes have suffered for the same reason and never got ripe and as a consequence the wine was of inferior quality' (Franzini, 1817)

In the Algarve region (southern Portugal), the 1816 cool summer weather effects on agriculture have also been reported (scarce and bad quality fruit, late ripening dates, problems concerning cattle raising, Chaves, 1817). One positive consequence on public health took place: 'The diseases due to hot weather and the influence of gases from the swamps, like dysentery, intermittent and bilious fevers did not happen. On the contrary, inflammatory diseases [usual in winter] were frequent, also in southern Portugal. Among these, scarlet fever has attacked a lot of people during the years 1815 and 1816' (Chaves, 1817).

\subsection{Relevant information from documentary sources} in Spain

\subsubsection{Testimonial evidence related to heat deficit}

In general terms, the testimonies obtained for Spain refer to a 1816 summer of extraordinary low temperatures. In the city of Barcelona, the lack of heat in the summer months was regarded not only as a worthy topic of conversation, but also as something negative and unusual. The diary of the Baron of Malda who lived in Barcelona shows how, on numerous occasions, the summer felt more like spring, and that this was a strange and uncomfortable sensation (Barriendos and Llasat, 2003). He compared the temperature on 18th August 1816 with that of a typical day in May. On the 22nd August he corrects this opinion and says that it was more like April (Barcelona City Archives, Manuscripts Section, 'Calaix de Sastre', Baron of Maldá, Ms. A-252, August 1816).

In his diary, the Baron of Malda refers to the possible causes of this unusual cold spell and associates it with a big snowfall event that took place in the centre of Spain on 11th August, which he later changed to 16th July. He also noted that there had been heavy snow in the Pyrenees and in northern Europe. This information cannot be confirmed from other sources but it is significant that the two dates provided by the Baron coincide with very low temperatures recorded in Madrid in the daily observations at 7 a.m. (16th July: $13.1{ }^{\circ} \mathrm{C}$ and 11 th August: $12.5^{\circ} \mathrm{C}$ ). It is possible that the snow was in fact a hailstorm over a large area in the central Spanish high plateau.

The general impression of an unusually cold summer can however be confirmed, as the Baron records all the particularly cool or cold days in his diary. According to the Baron, the months of July and August were particularly severe with 13 and 10 days of cold weather, respectively, while in June (5) and September (4) cooler events were experienced. We believe that this evaluation reflects two facts of a different nature: (1) these two months did register particularly low temperatures in Barcelona (Figure 5), (2) these two months correspond usually to the peak of summer temperatures, therefore unusually cold weather has a larger psychological impact, which might explain why June and July are characterized differently while their long-term monthly anomaly is similar (Figure 5).

After the summer of 1816, the unusual temperatures were perhaps not so obvious but it was still surprising that on the Mediterranean coast, in the middle of autumn, there were situations that were more typical of a very severe winter: 'As a demonstration of early cold weather, not only is Montseny mountain (1700 masl covered in snow, but also Montserrat mountain (1250 masl) and the surrounding areas. Moreover, it seems that the River Llobregat is frozen, a remarkable thing, and this is why everyone is staying well in doors' (Barcelona City Archives, Manuscripts Section, 'Calaix de Sastre', Baron of Maldá, Ms. A-252, 18th November 1816). 
In the rural areas, the cold temperature phenomenon had a direct negative impact on crops, similar to what was previously described for western Iberia (Portugal), as it significantly delayed the ripening process. In the case of cereals, the harvest was seriously affected as the farm workers had to select the ripe grain from the unripe ones which meant that labour costs were high. The spatial extent of the abnormal impacts in agriculture were not restricted to mainland Spain, as the important archipelago of the Balearic Islands in western Mediterranean (Figure 2) also suffered the burden: 'I note here as something strange and worthy of comment that throughout the months of June and July it was not at all hot. If anything it was cold, because of the excessively cool sea air caused by the hail that fell in Mallorca and other places. This delayed the wheat harvest, which continued throughout June and well into July. The dry wheat had to be carefully selected from the green that was left to ripen in the fields. In our estate there was still wheat to be harvested on St James' Day (25th July), which meant that threshing was also late, because there was no sun and it was misty all day and clear all night, quite the opposite of what was needed' (Archives of Arenys de Mar, Memòries de la casa Belsolell de la Torre, 1816, p. 98).

Similarly to what happened to the cereals the wineproducers noticed (by the end of August 1816) that the lack of heat was preventing the grapes from ripening and therefore, that the harvest in that year would be poor in terms of both quantity and quality (Barcelona City Archives, Manuscripts Section, 'Calaix de Sastre', Baron of Maldá, Ms. A-252, 27th August 1816).

\subsubsection{Testimonial evidence of delayed impact due to lack of rain}

There are very few direct testimonies as to the dates, magnitude and duration of droughts in Spain, but this information can be obtained from proxy data such as the records of agricultural production and prices (García et al., 2003), or the records of special religious ceremonies held to ask God for rain (Martín-Vide and Barriendos, 1995; Barriendos, 1997, 2005). With the information we have about these rogation ceremonies in six Spanish towns or villages, it would seem that there was a severe, if unevenly distributed drought between 1815 and 1818 with a maximum widespread amplitude in 1817 (Figure 3). This intense reduction was observed throughout the whole year of 1817 , without a particular focus on any season. In any case, the spatial configuration of this drought is variable in time, a fact that might be partially related to the large orographic complexity of Iberia and the corresponding large spatial gradients of precipitation characteristics (e.g. Rodríguez-Puebla et al., 1998; Serrano et al., 1999).

Contemporary accounts describe the most severe examples of the problems caused by the drought namely the loss of cereal crops, the shortage and the high prices reached for many essential products (e.g. bread, milk, vegetables). At the end of 1817, the situation was particularly bad in many cities and villages. For example, of the 30 wells that normally supplied water to the townspeople of Arenys de Munt (40 km NE of Barcelona) only 6 had water, moreover this water was turbid and of poor quality. Naturally, the hydraulic energy obtained in watermills was also severely reduced. All the watermills in the area were left dry and what little flour there was had to be produced in Girona ( $60 \mathrm{~km}$ away) or at two emergency mills (so-called 'blood-mills') driven by people and horses (Archive of Arenys de Mar, Memòries de la casa Belsolell de la Torre, 1816, p. 99).

It will be shown later that meteorological readings taken in Barcelona show that there was a prolonged period of drought from 1812 to 1818 with the worst year being precisely 1817 .

\section{Relevant information from meteorological observations}

A considerable number of educated people started to perform more-or-less regular meteorological observations in the second part of the 18th century in the SW sector of Europe (Barriendos et al., 1997; Taborda et al., 2004; Vaquero and Trigo, 2005; Luterbacher et al., 2006). However, as mentioned in the introduction, these early significant efforts were hampered to a great extent by
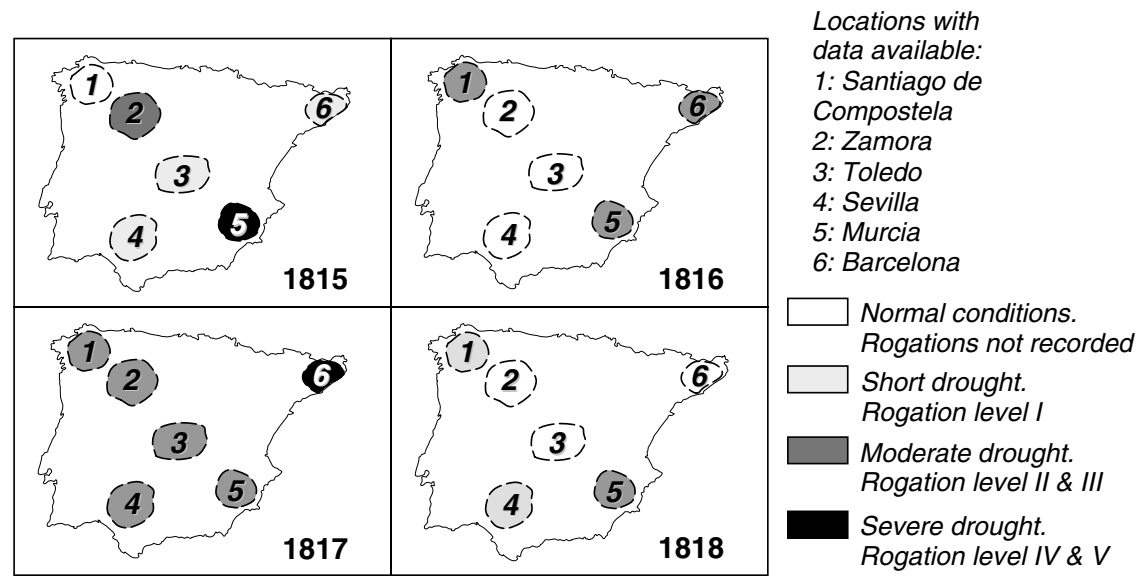

Figure 3. Drought rogation ceremonies over Spain (Rogation levels criteria from Martín-Vide and Barriendos, 1995). 
the end of the 18th century and in the early years of the 19th century, partially as a consequence of political upheavals in both countries including the highly perturbing Napoleonic wars (Taborda et al., 2004).

\subsection{Portugal}

In the early 19th century, the most prominent meteorological observer in Portugal was Marino Miguel Franzini (1779-1861), who had a degree in higher military studies. He was deeply interested in meteorological phenomena and kept in touch with foreign meteorologists from numerous academies of sciences. In particular, he performed regular meteorological observations in Lisbon and Sintra $(30 \mathrm{~km}$ from the Portuguese capital to the westnorthwest (WNW). The first data published by Franzini refers to the period that ranges between December 1815 and the end of 1817 and were issued in the Memórias of the Portuguese Science Academy (founded in 1779). Franzini's meteorological observations started on the suggestion of Doctor Gomes, who needed meteorological data to analyse public health and mortality evolution in Lisbon (Alcoforado et al., 1999). From 1818 onwards, data were published in the weekly and monthly press, particularly within medical journals. Unfortunately, no daily data are to be found because Franzini has gathered information in groups of so-called 'homogeneous' days (averages were calculated for consecutive days characterized by similar weather patterns).

Franzini describes in detail the site of the meteorological station he had installed in S. Pedro de Alcântara (Lisbon), 72 masl, on a platform opened to the NE, E and SE (like the actual Lisbon meteorological station, placed a few hundred metres to the NW and 97-m high). The meteorological instruments were excellent in quality and have been described by Franzini. The details given by Franzini (1817, p. 104) referring to the thermometer, the barometer, the wind vane and the pluviometer show that all the instruments were very carefully designed. Only the wind force was subjectively determined.

Until now two series of monthly data were reconstructed referring to Lisbon: December 1815-1825 and 1836-1854. Franzini's time series are currently being analysed for possible inhomogeneities, this work is being done within the context of constructing the longest time series for Lisbon. Contrasting with the amount of information on the Lisbon series obtained by Franzini, almost no information is available for the remaining observed time series over Portugal, namely Coimbra and Porto (Figure 2).

\subsection{Spain}

There are very few instrumental series available in Spain for the period being studied (1810-1820). At the moment, we only have continuous data for three series: Cádiz/San Fernando, Madrid and Barcelona (Figure 2).

The observations in Cádiz/San Fernando began in 1786 but were not carried out on a continuous basis until 1820 (Barriendos et al., 2002; Rodrigo, 2002; Vinther et al.,
2003). These were the official observations made at the Observatory of the Spanish Navy, which was initially located in Cádiz and in the 19th century was moved to its current location in San Fernando, $6 \mathrm{~km}$ away. The observation methods and instruments used varied greatly from the time the observations began until a modern meteorological observatory was set up in 1870. As part of the Project IMPROVE, these observations were studied and a series were prepared according to the criteria used in modern readings (Barriendos et al., 2002). We were able to correct and adjust the data produced for different hourly periods to calculate an average daily temperature, thanks to the fact, that hourly meteorological observations ( 1 observation/h) have been carried out in San Fernando since January 1870.

The Madrid series has been put together, since 1786, by different doctors and scientists using different observation criteria (Barriendos et al., 1997; Brunet et al., 2006). Over the first half of the 19th century the data are relatively continuous with three temperature readings per day, usually obtained at 7 a.m., 12 a.m. and 5 p.m., respectively. The data have not been corrected and rescaled, because there are no metadata available regarding the observation conditions. The exact location of the observatory and any changes are unknown, and it is possible that some of the readings were taken indoors rather than in the open air. This means that it would be a very complex task to convert these figures into data that comply with current observation criteria.

The Barcelona series began in 1780 and has been assembled also by medical doctors until it was replaced by the first official observations in 1885 (Rodríguez et al., 2001). Little is known about the observation information. It is known that the first observer, Francisco Salvá worked at home, in the open air, with his instruments facing north. He made three observations in a day, i.e. at 7 a.m. in the morning, 12 a.m. and 10 p.m., respectively. This system continued until 1885 when the Barcelona University published the first official figures based on two daily observations at 8 a.m. and 3 p.m. It is still, therefore, very difficult to calculate a monthly average value. In fact, although we do have the original observations, we have very little information as to the methods and instruments used. Lastly, the frequent changes during the 19th century in Barcelona have forced us to give up the idea of making a series with modern data, which would also be greatly affected by the urban heat island effect in the city. A continuous series of 210 years has only been established for atmospheric pressure, and for the second half of the 20th century, the information used was retrieved from the observatory at Barcelona Airport about $15 \mathrm{~km}$ away from the site, where the observations were made in the 18th and 19th centuries (Rodríguez et al., 2001).

\section{Analysis of temperature and precipitation anomalies}

It should be stressed that, despite the availability of daily data for Cádiz, all analysis is performed with monthly 
averages. After a preliminary checking of all time series (monthly averages of minima, maxima and mean values), it becomes evident that the temperature data for Coimbra and Porto (northern sector of Portugal, Figure 2) had serious problems regarding a small diurnal temperature range (maximum minus minimum temperatures). Such low values of temperature range are usually a clear indication that the thermometer was installed indoors, which makes the comparison of values with 'present climate' data particularly difficult. Therefore, these two series were disregarded from the rest of the analyses. For the remaining stations, we computed monthly anomalies for the mean temperature, after removing the long-term climatological normal corresponding to the period 1871-1900, not contaminated by global warming. Results of monthly temperature anomalies, computed between 1816 and 1820, for the four stations retained are shown in Figure 4.

Overall there is a general agreement among stations, except for Barcelona, where a systematic error (positive bias) affects the entire period depicted. During the year 1816, there's a predominance of negative anomalies, particularly intensive during the summer of 1816. In fact, the largest negative anomalies for these years in Lisbon, Madrid and Cádiz are concentrated around the summer months of July and August, with values near $-3^{\circ} \mathrm{C}$ being observed. Interestingly, the early months of 1817 are characterized by positive anomalies for all considered stations, with February and March considerably warmer than usual. The following summer of 1817 is characterized by cold anomalies (albeit milder than in 1816) in
Lisbon, Cádiz (Figure 4) and Barcelona (Figure 5) while Madrid presents slightly positive anomalies.

The temperature series for Barcelona clearly reveals some 'problems' that are most probably related with the singular use of three daily values to compute the daily average (as explained in Section 3.2) that makes it particularly difficult to establish a direct comparison with the climate computed for 1871-1900. Therefore, we present an equivalent graphic for the monthly temperature anomalies computed between 1816 and 1820, for Barcelona, but after removing the long-term climatological average for the period 1780-1815 (Figure 5). The cold months of summer 1816 stand clearly as the most significant cold anomaly for this period in good agreement with the corresponding summer anomalies for the other three stations (Figure 4). For Barcelona, the annual average for 1816 in Barcelona, is the lowest value for the period 1780-1825. It is interesting to note that independent tree-ring based summer (May-September) temperature reconstructions for the Pyrenees dating back to AD 1260 (Büntgen et al., 2008) also point to similar negative temperature anomalies as presented for Barcelona (not shown).

The quality and methodical nature of observations undertaken by Franzini in Lisbon were stressed in Section 3. Therefore, we decided to further analyse the full data set available for this city, namely monthly averages of maximum, minimum and mean temperature. Results are shown in Figure 6, where all anomalies were also computed against the 1871-1900 reference period.
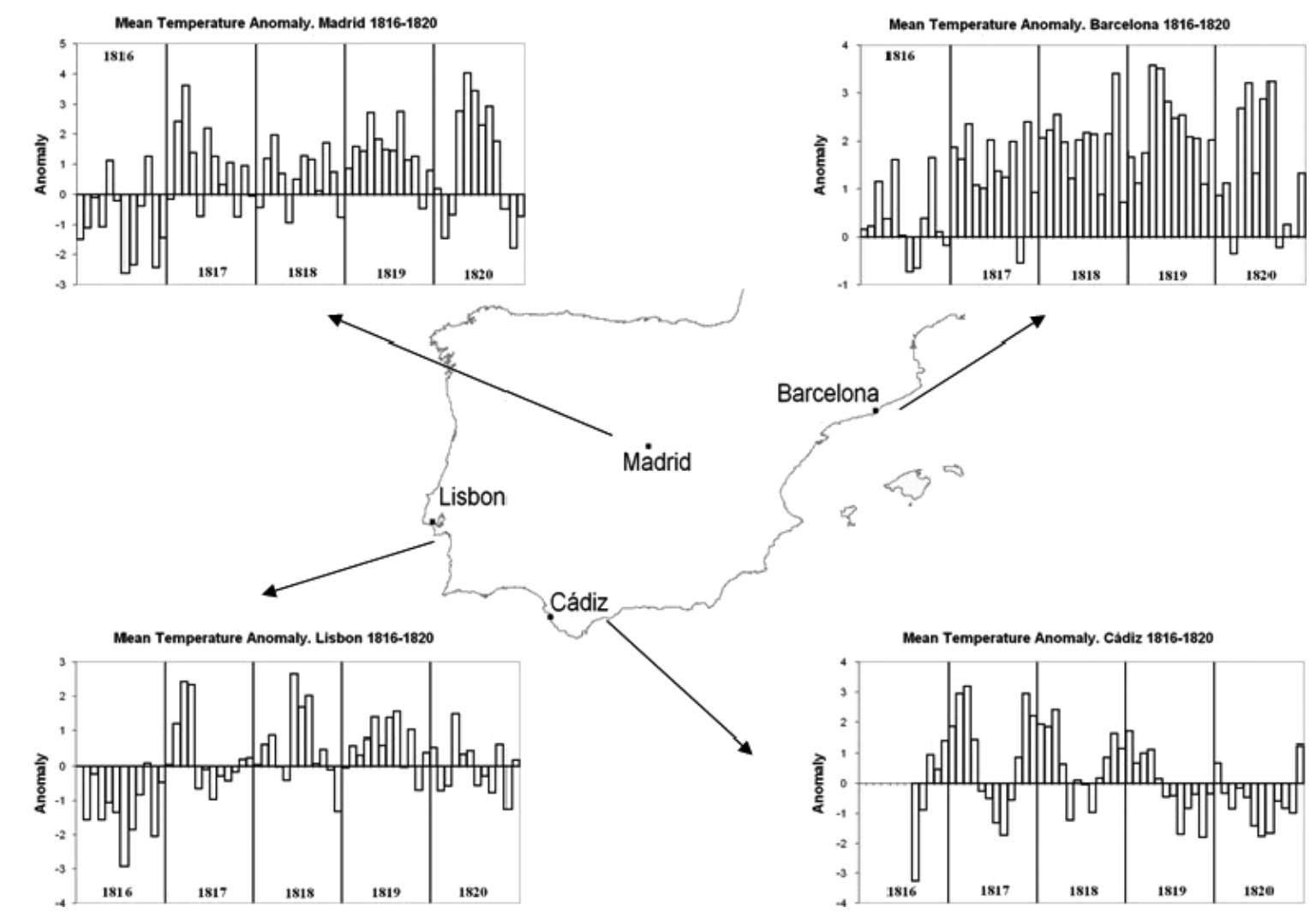

Figure 4. Monthly mean temperature anomalies (with respect to 1871-1900) between 1816 and 1820 for Lisbon, Madrid, Cádiz and Barcelona. 


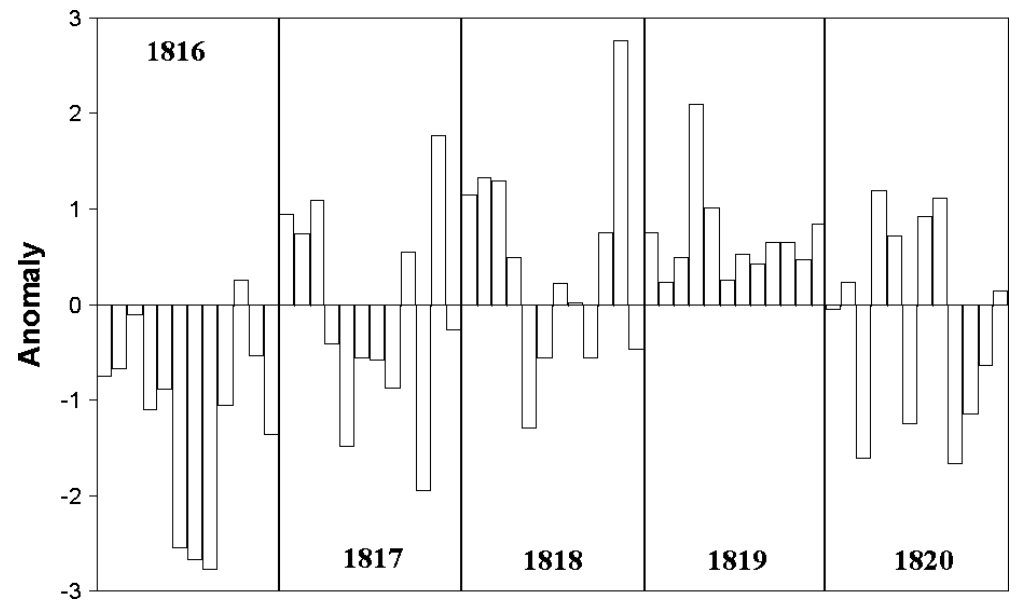

Figure 5. Monthly mean temperature anomalies (with respect to 1780-1815) between 1816 and 1820 for Barcelona.
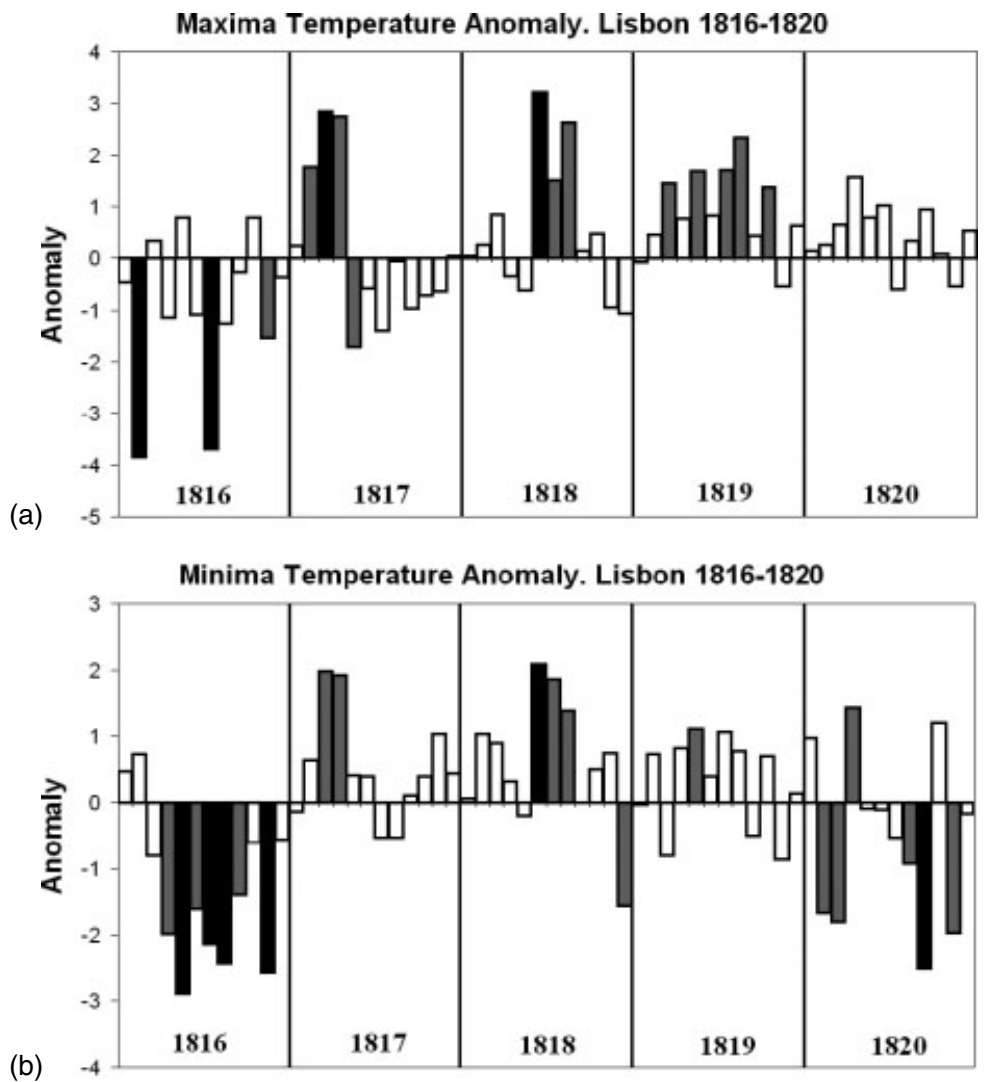

(b)

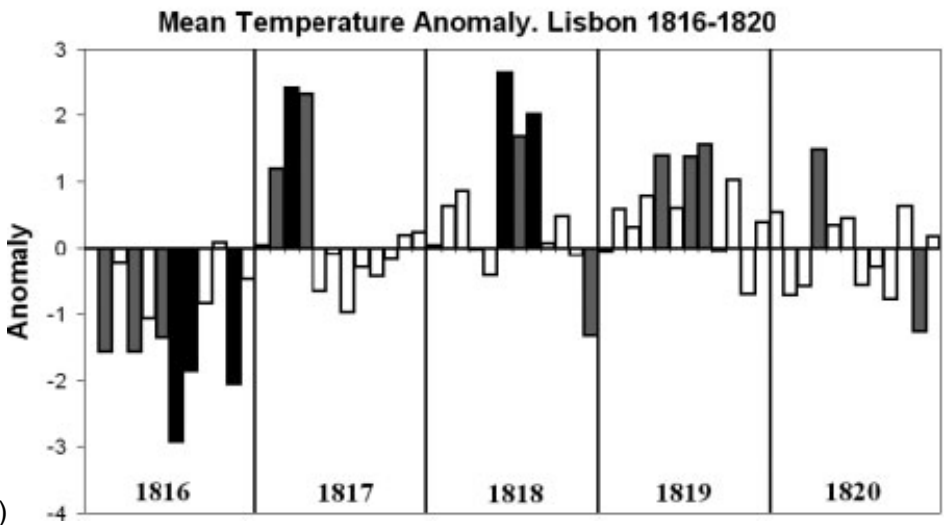

Figure 6. Monthly maximum (a), minimum (b) and mean (c) temperature anomalies (with respect to 1871-1900) in Lisbon during the period 1816-1820. The dark (light grey) bars indicate that the temperature of that month surpassed the interval of two (one) standard deviations with respect to $1871-1900$. 
Different shaded colours in Figure 6 are indicative of the relative magnitude of these anomalies with black (grey) bars indicating that the temperature of that month surpassed the interval of two (one) standard deviations with respect to 1871-1900. The vast majority of anomalies for the year 1816 were negative, particularly between spring and autumn. February 1816 was a remarkable month with Tmax revealing a negative anomaly close to $-4{ }^{\circ} \mathrm{C}$ contrasting with the positive anomaly depicted by the Tmin, corresponding to a significant decrease of the average diurnal temperature range. Therefore, the graphical representation of the monthly average temperature anomalies (Figure 6(c)), also represented in Figure 4 (without the shaded bars), is incapable of representing the true amplitude of the anomalous extreme temperatures observed during these years. The most important features for 1817 , is the appearance of a significant positive Tmax anomaly between February and April, followed by seven consecutive months with negative anomalies. Between 1818 and 1820, there is a seasonal cycle of anomalies for both Tmax and Tmin, with spring and summer being dominated by positive anomalies while winter is mostly characterized by negative anomalies.

In Section 3.1, we have shown documentary sources confirming the wet nature of the 1816 summer months for Portugal. Here we have also analysed the corresponding precipitation anomalies for Lisbon (Figure 7(a)), where all anomalies are shown as percentage with respect to the 1961-1990 climatology. Results are considerably less clear-cut than those obtained for temperatures. Probably the most interesting features are related to the confirmation of the wet nature of the summer of 1816 (particularly during July and August), and the relatively dry winter of $1816 / 1817$ and early spring of 1817 . Results for the southern station of San Fernando (Figure 7(b)) and northeastern Barcelona (Figure 7(c)) are also represented.

Unlike many countries in central and northern Europe, the precipitation regime in both Portugal (Trigo and DaCamara, 2000) and Spain (Rodríguez-Puebla et al., 1998; Gonzalez-Rouco et al., 2000; Trigo and Palutikof, 2001) is highly seasonal with scarce precipitation in the summer months, particularly between June and September. This is why precipitation anomalies in Figure 7 are represented in percentage, allowing for an easier comparison between different stations and among different months. An anomaly of $20 \mathrm{~mm}$ in August can be more significant (in the statistical sense) than a corresponding anomaly of $50 \mathrm{~mm}$ obtained for January. The highly significant anomalies depicted in Lisbon for the months of July and August of 1816, and month of September of 1817 correspond to relatively small precipitation totals. This fact is necessary to understand why so many people in Portugal refer to the wet summer of 1816, although the total amount that fell in that particular season was less than what is registered in a typical dry winter. In fact, just a few consecutive rainy days in August are so rare, that such an event will be easily remembered by many people.
On the basis of Figure 7 it seems however, that the winter of $1816 / 1817$ and the following spring of 1817 were relatively dry in all three sectors of Iberia covered by these stations (although data from San Fernando was only available after January of 1817). In fact, based on the values from the three stations available, it is possible to state that the most important rainy season in Iberia (winter) was consistently dry between 1816 and 1819 in accordance with the results of the only work that had evaluated the impact of major tropical eruptions in the Iberian precipitation (Prohom and Bradley, 2002). It should be stressed that the precipitation total for 1817 in Barcelona was less than $200 \mathrm{~mm}(196.3 \mathrm{~mm})$, roughly three times less than the long-term average value $(573.7 \mathrm{~mm})$ for the entire period with data (1786-1996), corresponding to the lowest value ever recorded in this city. Furthermore, as previously mentioned, the sevenyear drought (1812-1820) was the most exceptional, recorded in the Barcelona area since the start of precipitation measurements (Barriendos and Dannecker, 1999). The months of May and September of 1817 are also abnormally wet in San Fernando, although not as much as in Lisbon. Interestingly, these two months (May and September of 1817) contrast with the dry conditions that characterize the remaining year for all three stations.

\section{Comparison of results with independent climate reconstructions}

In this section, we present a comparison between local (stations discussed above) seasonal temperature anomalies with European scale climate reconstructions. It is important to note, that the field reconstructions do not incorporate any of the station information presented here, thus the two fields can be considered independent. For that purpose, we have used seasonally averaged reconstructed high-resolution $\left(0.5^{\circ} \times 0.5^{\circ}\right)$ land surface temperature (Luterbacher et al., 2004, recalculated using only temperature predictors) and sea-level pressure (Luterbacher et al., 2002, at $5^{\circ} \times 5^{\circ}$ spatial resolution, recalculated using only station pressure series). In recent years, the use of superposed epoch analysis has been widely used to compute the impact of large eruptions on climate (e.g. Sear et al., 1987; Bradley, 1988; Prohom and Bradley, 2002; Prohom et al., 2003; Adams et al., 2003; Písek and Brázdil, 2006; Fischer et al., 2007). Unfortunately, in our case such an approach is not possible because of the inexistence of continuous station data prior to 1816 in both Lisbon and Cádiz, moreover we are dealing with only one eruption event. Therefore, we decided to maintain the standard normal period (1871-1900), that was already used in the previous sections, as baseline period to compute all anomalies. Figure 8 shows the winter (left) and summer (right) seasonal anomalous temperature fields for the years 1816-1818. For comparison purposes, observed seasonal temperature anomalies for Barcelona, Madrid, Cadiz and Lisbon are also presented.

From Figure 8, the following points can be highlighted: 

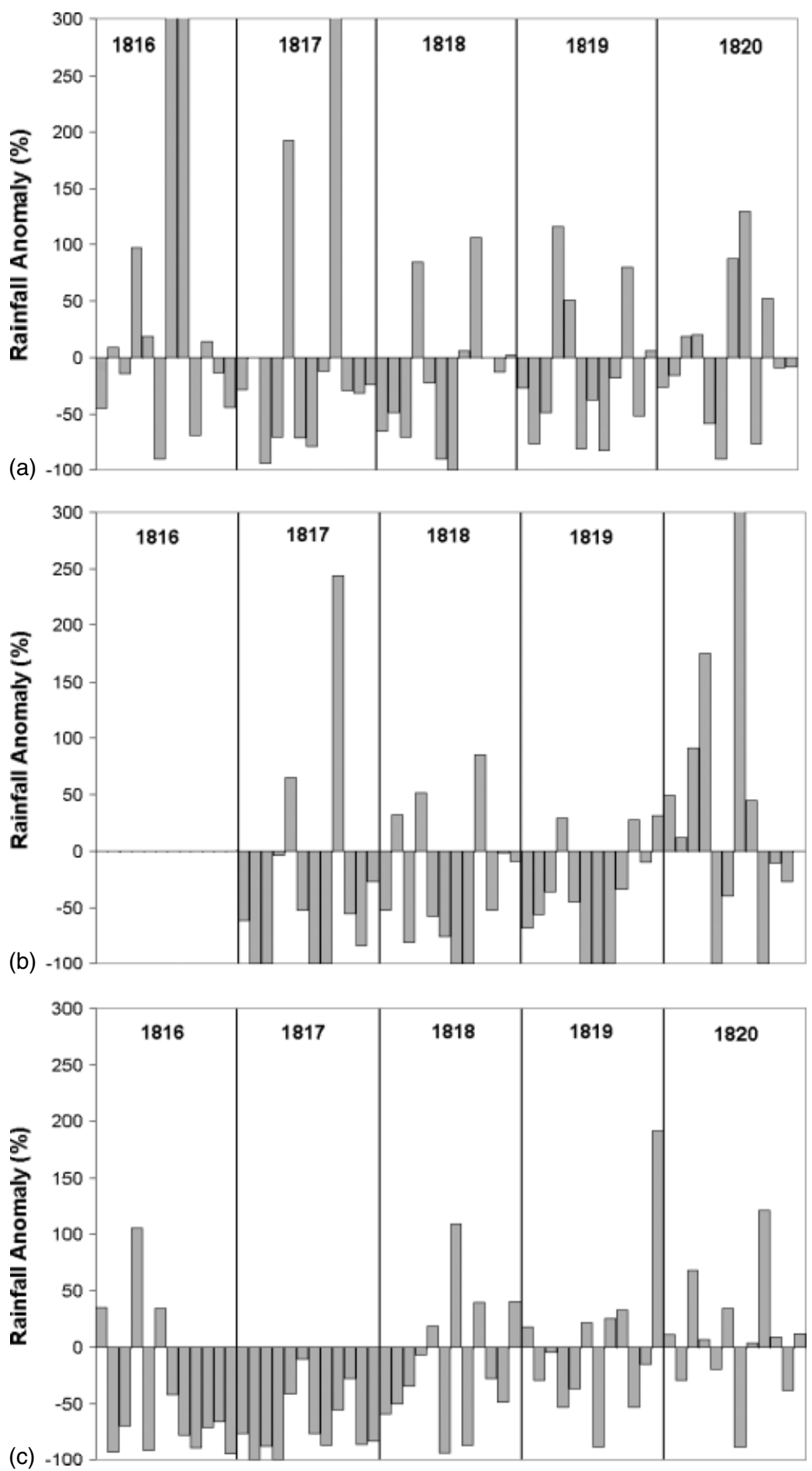

Figure 7. Monthly rainfall anomalies in percentage for Lisbon 7(a), San Fernando 7(b) and Barcelona 7(c) between 1816 and 1820 . Anomalies in percentages were computed in relation to the corresponding monthly averages for the period 1961-1990. This graphic is limited for negative anomalies (a month with no rainfall presents a-100\% anomaly) but is not limited for positive anomalies. We have introduced an upper limit of $300 \%$ to facilitate the visualization, but this limit is surpassed in Lisbon (July and August 1816, September 1817) and in San Fernando (July 1820).

1. The spatial distribution of reconstructed temperature anomalies for the two summers after the Tambora eruption (1816 and 1817) reveals strong negative anomalies throughout western Europe (Luterbacher et al., 2004), in accordance with previous results (Briffa et al., 2004; Písek and Brázdil, 2006). These summer 'cold' patterns are in agreement with the typical temperature anomalous pattern associated with large tropical eruptions in Europe as shown in Figure 1 of Fischer et al. (2007).

2. Differences between observed and reconstructed anomalous values are, in general, smaller in Barcelona compared to the other stations. In particular, the observed temperature anomaly for the summer of 

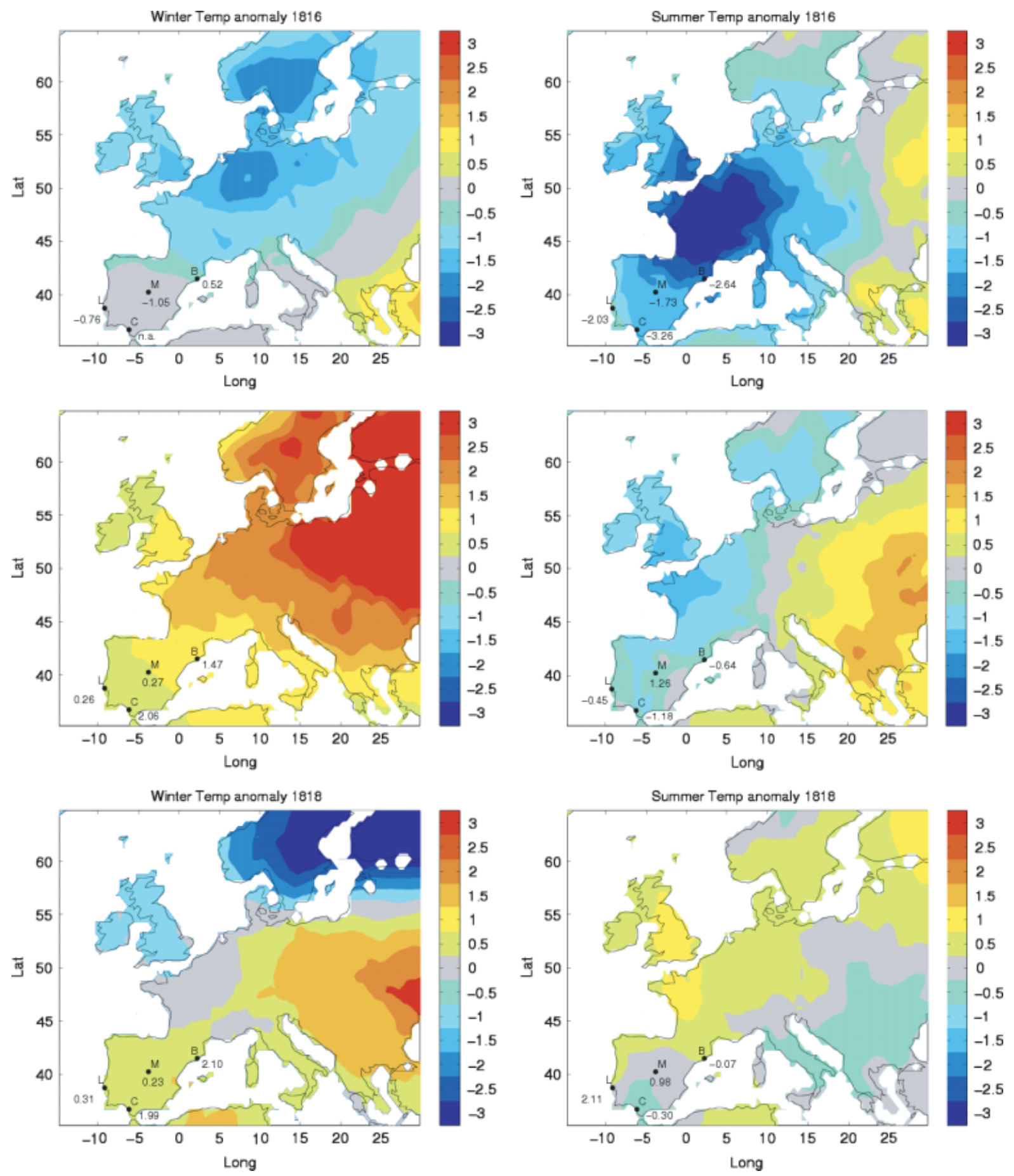

Figure 8. Seasonal reconstructed temperature anomalies $\left({ }^{\circ} \mathrm{C}\right.$, colour) for winter (left) and summer (right) for the years; 1816 (top), 1817 (middle) and 1818 (bottom), with respect to 1871-1900 (from Luterbacher et al., 2004). The four Iberian stations, with observed data, are identified by their initials and the observed temperature seasonal anomalies are also given. The 1816 summer temperature in Cádiz corresponds only to the month of August.

1816 is similar to the reconstructed value. Observed seasonal anomalies, for the two following summers, are considerably smaller and the reconstructed field captured well the smaller amplitude of these anomalies. For the three remaining stations, the picture is more complex. However, during 1816 (both winter and summer) observed anomalies in Madrid, Lisbon and Cádiz are systematically stronger than the corresponding reconstructed values.
3. It is worth noticing that, according to the anomalous reconstructed temperature for the summer of 1816 , the bulk of the negative anomaly (exceeding $-3^{\circ} \mathrm{C}$ ) extends between western Germany and northern Spain covering France, southern England and Switzerland. From the European perspective, this large area corresponds to the most affected area by the so-called 'year without summer'. This reconstructed negative anomaly decreases considerably over Iberia, 
going from the north-eastern (border to France) to the south-western region. Nevertheless, according to our observations, the region with temperature anomalies exceeding $-2{ }^{\circ} \mathrm{C}$ may well be extended to the western (Lisbon) and southern (Cádiz) sectors of the Iberian Peninsula. Nevertheless, we should stress that, owing to the lack of data, the summer 1816 anomaly temperature value for Cádiz is restricted to the month of August.

4. The reconstructed field for the winter of 1816 (Figure 8, top left) is characterized by strong negative anomalies in northern Europe. As pointed out by Fischer et al. (2007), the winter temperature response is stronger in year one than in year zero (thus stronger in 1817 than in 1816). It is suggested that this time-lag, also noted in a General Circulation Models (GCMs) study by Yoshimori et al. (2005), is due to the time taken for the temperature gradient, which forces the dynamical winter response, to fully establish itself. Another indication stems from the reconstructed North Atlantic Oscillation index (NAOI) for that particular winter: Luterbacher et al. (1999); Glueck and Stockton (2001); García et al. (2003); Vinther et al. (2003) as well as Cook et al. (2002) all point to the fact that the winter NAOI of 1816 was only slightly positive compared to the positive value in winter 1817 . Rodrigo et al. (2001) even report a negative winter $\mathrm{NAO}$ in 1816 . In any case, the very intense positive temperature anomaly obtained for the summer of 1817 (Figure 8 (b), middle left), with positive anomalies exceeding $3{ }^{\circ} \mathrm{C}$ in Scandinavia and the Baltic region is in accordance with the results by Fischer et al. (2007) that reported a larger warming for the second winter after strong tropical eruptions.

5. Reconstructed temperature for the year 1818 reveals, in general, smaller anomalies compared to 1816 and 1817 , particularly in the summer which is in agreement with the typical impact of large eruptions on European climate that usually lasts up to 3 years (Fischer et al., 2007).

It should be stressed, that we have always used the 1871-1900 reference period, that is not contaminated by the recent global warming trend. However, the eruption of Krakatau occurred in 1883 and could affect the use of this 30-year long period as an appropriate reference period. Therefore, we have repeated the same computations but excluded the years after the Krakatau eruption (i.e. using the period 1868-1900 without the years 1884-1886). The obtained patterns and results were very similar to what we have obtained here, therefore, not affecting in any way our statements and conclusions (not shown).

Figure 9 presents independently reconstructed anomalous sea-level pressure fields for the winters and summers of 1816-1818 with respect to the 1871-1900 reference period (Luterbacher et al., 2002, though reprocessed using only station pressure data). The winter and summer 1816 anomaly fields point to a strong negative SLP anomaly centred over southern Scandinavia. The Iberian
Peninsula is situated at the south-western part of that anomaly, connected with anomalous north-westerly flow towards the area of interest. This SLP anomaly pattern provides the necessary framework to explain the positive precipitation and negative temperature anomalies detected over northern Europe in the winter of 1816 (Figure 8). The winter of 1817 indicates a strong anomaly dipole pattern with a well-developed Azores high and a strong Icelandic low, typical of a positive NAO pattern. The Iberian Peninsula is influenced by the strong Azores high, connected with dryness (Figure 7) and mild temperature conditions (Figure 8). During summer of 1817, the anomalous low pressure zone is displaced towards the south and west of the United Kingdom, influencing the Iberian Peninsula with temperatures generally below normal (Figure 8). In winter of 1818 , the pressure gradient over the eastern North Atlantic is weaker again. Except for the northern part, the Iberian Peninsula is strongly influenced by the Azores high compared to the 1871-1900 period. This pattern is, once more, responsible for the dry conditions observed in the three stations available (Figure 7). The SLP anomaly pattern for summer of 1818 indicates a strong positive anomaly covering large parts of Europe, including the Iberian Peninsula.

Straightforward comparisons between observed values for our three stations (Lisbon, Madrid and San Fernando) and high-resolution precipitation reconstructed fields are not trivial. Unlike temperature (Figure 4), precipitation anomalies vary considerably from month to month within a specific season (Figure 7), therefore seasonal anomalies are incapable of representing the intraseasonal variability. However, we have studied the most recent high-resolution historical reconstructed precipitation fields from Pauling et al. (2006) that have used multiproxy data to reconstruct European seasonal precipitation back to 1500 . For the winter of 1816 , those precipitation field reconstructions point to a slightly drier (wetter) northwest (southwest) of the Iberian Peninsula. During summer, the results do not return significant differences (not shown). Concerning winter of 1817, there is a distinct dry pattern over the entire Iberian Peninsula with strongest negative precipitation departures over the southwest, while during the summer months the west (east) of the Peninsula shows slightly wetter (drier) conditions (not shown). The winter precipitation anomaly pattern of 1818 is very similar to winter anomaly of 1817 . For summer, the northern part points to drier conditions, whereas the central regions indicate slightly wetter conditions (not shown). Therefore, we can say that results based on Pauling et al. (2006) are generally consistent with those attained in our analysis.

\section{Discussion and summary}

This article provides the first direct assessment of the impact of the Tambora's eruption in Iberia, derived from historical documents and also from early observations from stations in Spain and Portugal recently 

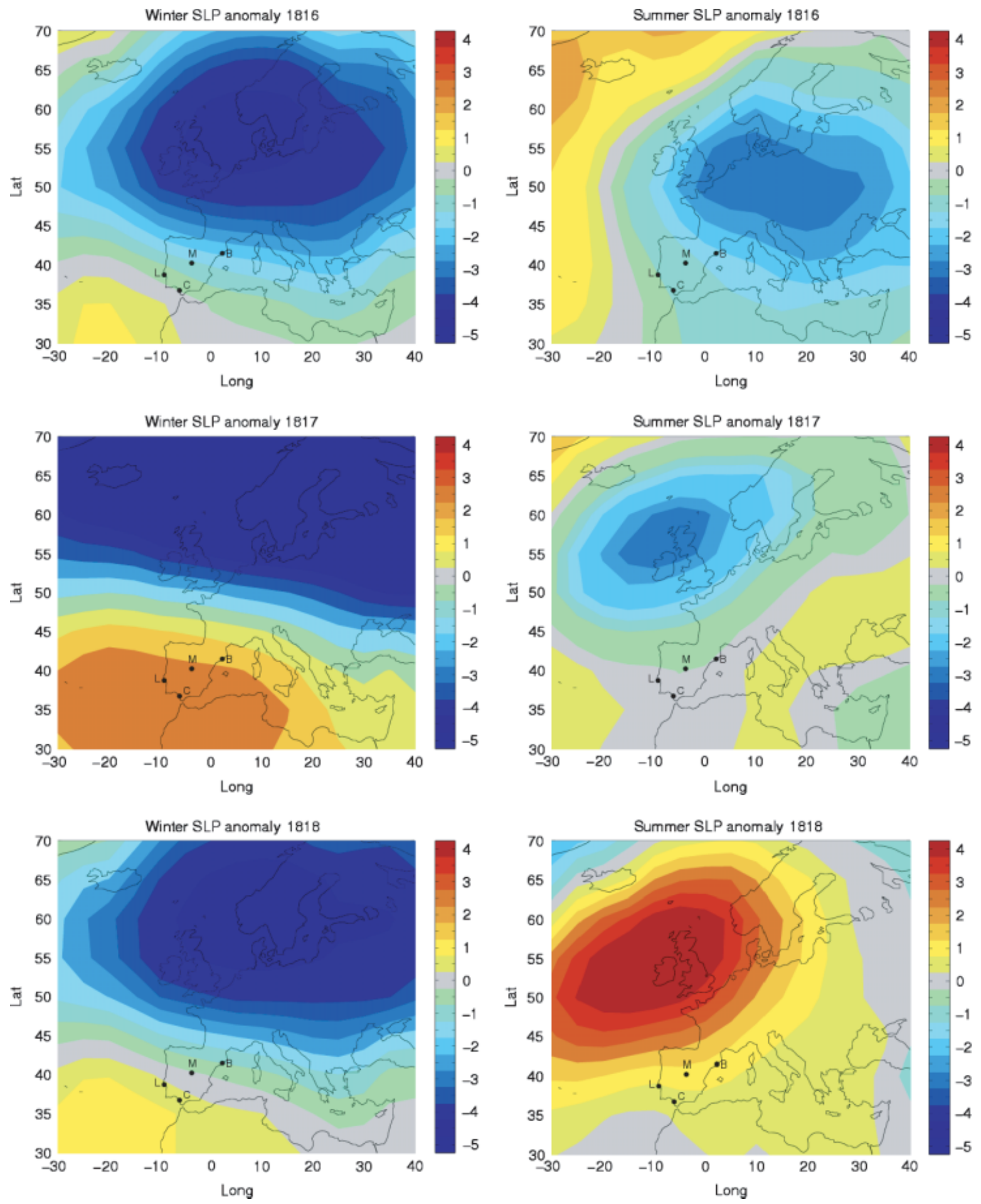

Figure 9. As Figure 8, but for seasonal reconstructed SLP anomalies (from Luterbacher et al., 2002) (hPa, colour).

re-discovered. Apart from our analysis for the year 1816, the so-called 'year without a summer' we also considered the peculiar climatic context of the early 19th century, characterized by a minimum of solar input and a higher than usual volcanic activity. Monthly anomalies of temperature (Figures 4 and 5) and precipitation (Figure 6) were evaluated for the entire pentad after the occurrence of Tambora in 1815, i.e. between 1816 and 1820 .

Documentary sources from Spain and Portugal were used in order to evaluate weather and climate in the
Iberian Peninsula. Most of these documentary evidence sources describe the impact that the cold and wet summers of 1816 had on the agriculture; the bad quality of fruits, delayed ripening of vineyards and cereals, which seriously undermined production yields. Summer temperature anomalies in the following year of 1817 remained considerably below average over Iberia (Figures 4, 5 and 8), prolonging some of these agricultural production problems. Drought rogation ceremonies help to confirm that 1817 was a very dry year over the entire Iberian 
Peninsula, particularly in the north-eastern region (where Barcelona is located). However, a sequential analysis of these ceremonies between 1815 and 1818 reveal that dry conditions were already being observed in some sectors of Iberia in 1815 (Figure 3).

There are different estimates of the temperature impact for the $1816 \mathrm{NH}$ temperature anomaly associated with Tambora, ranging between -0.4 and $-1.0^{\circ} \mathrm{C}$ (Stothers, 1984; Vupputuri, 1992; Oppenheimer, 2003). These hemispheric analyses are non-representative of the actual anomalies occurring at the more regional scale of Europe. Recent higher resolution temperature reconstructions for Europe allow in inferring the impact of this eruption at considerable smaller scales (e.g. Pisek and Brazdil, 2006; Fischer et al., 2007). According to Briffa et al. (2004), the temperature was $-2{ }^{\circ} \mathrm{C}$ lower for $\mathrm{NE}$ Iberia, while in the rest of the Peninsula, the reconstructed anomaly values fell within the -1.2 and $-2{ }^{\circ} \mathrm{C}$ range. Our results suggest that the anomalies were probably stronger than $-2{ }^{\circ} \mathrm{C}$ for the majority of the Iberian Peninsula territory. Naturally, there are open questions about the level of homogeneity of the station data used, in any case it should be stressed that we are not constructing long-time series, neither are we trying to elaborate on the existence of longterm climatic trends. We are merely looking at monthly anomalies of temperature and precipitation without the use of higher statistical moments, namely variance.

The comparison with high-resolution spatial temperature fields (Luterbacher et al., 2004) indicates that the summer of 1816 returns relatively minor temperature anomalies for western (Lisbon), central (Madrid) and southern (Cadiz) sectors of Iberia. Thus, the Tambora impact in Iberia has been underestimated by different temperature reconstruction approaches, probably due to the scarce number of available proxy chronologies in SW Iberia (see Figure 1 of Briffa et al., 2004; Luterbacher et al., 2006).

Comparisons between observed and reconstructed fields are difficult to perform because of the different nature of time series under consideration. It is known that grid cells represent a different type of information (area average) in contrast to the local information character of station data series and, therefore grid cells tend to show less variability than stations (Osborn, 1997). Therefore, it seems expectable that the reconstructed temperature fields present, in general, anomalies with a smaller amplitude. The better performance of the reconstructed temperature field in the north-eastern Iberia (Barcelona) is probably linked to the existence of a higher density of proxies in those areas (Luterbacher et al., 2004; Xoplaki et al., 2005). Moreover, the fact that volcanic signal may be underestimated in tree rings records, might explain the underestimation of the volcanic response in the multiproxy reconstructions. Robock (2005) has shown that tree ring records may be biased by an enhanced tree growth for several years following each eruption induced by additional diffuse radiation caused by the stratospheric volcanic aerosol clouds. In fact, other proxies located far from Iberia might be well related with the winter
NAO index (such as Greenland ice cores). However, this relationship is not 'valid' for the summer and, even for winter, the temperature field is poorly linked to the NAO pattern over most of Iberia (Trigo et al., 2002). Therefore, our results indicate the possibility of using some of these data to improve temperature reconstruction quality for those years, particularly for western and southern Iberia.

The largest impact of tropical eruptions usually occurs 4-6 months after, depending on the season of the volcanic event, and is usually associated with an intensified stratospheric polar vortex (Robock, 2000). Unfortunately, some of our records start in December 1815 or August 1816 , hence we cannot verify the immediate characteristics of the post-eruption changes in Iberia. However, Figure 4 shows that the cold anomaly persisted in Iberia until the end of summer 1817 , being more consistent in Lisbon and Cadiz. This seems to be in agreement with Briffa et al. (2004) reconstruction and shows that the cooling profile in Iberia was rather different than that which occurred in Central Europe (Pisek and Brázdil, 2006).

A comprehensive analysis on precipitation anomalies is harder to perform owing to the scarce data availability and the large spatial variability that characterizes Iberian precipitation regime. Documentary evidences report heavy winter rains in Britain and western Europe, as well as increased storminess (Stothers, 1984; Oppenheimer, 2003). However, as seen in the previous sections, our data suggest a wetter than usual 1816 summer in Lisbon and general dry conditions in Barcelona. One should stress that the summer wet months in Lisbon correspond to relatively small absolute values of precipitation. Owing to the complex behaviour of the Iberian precipitation, it is difficult to make additional inferences on the Tambora's impact on the precipitation regime in the region.

\section{Acknowledgements}

Ricardo Trigo and Ricardo García-Herrera received support from the Portuguese-Spanish integrated action (E27/2005) funded by CRUP and MCYT and the EU 6th Framework Program (CIRCE). José M. Vaquero acknowledges support from the Gulbenkiam FoundationBiblioteca Nacional de Portugal, and the Programme 'José Castillejo' from the Spanish Science Ministry. Mariano Barriendos acknowledges the Research Programme 'Ramon y Cajal' and Research Group 'Paisatge $i$ paleoambients a la muntanya mediterrània', University of Barcelona. Jürg Luterbacher is supported by the Swiss National Science Foundation through its National Centre of Excellence in Research on Climate (NCCR) and the EU 6th Framework Program (CIRCE). Some of the historical Portuguese material used in this work was consulted at the Biblioteca Nacional de Portugal (Lisbon, Portugal) and Biblioteca del Real Observatorio de la Marina (San Fernando, Spain). Long-term series of observed data were also obtained through the Portuguese project SIGN (Signatures of environmental 
change in the observations of the Geophysical Institutes) under POCTI/CTA/47803/2002project. The authors are in debted to Manola Brunet and Javier Sigró for providing data for Madrid. Finally the authors would like to thank both reviewers for their helpful and constructive comments that help in improving the manuscript.

\section{References}

Adams JB, Mann ME, Ammann CM. 2003. Proxy evidence for an El Niño-like response to volcanic forcing. Nature 426: 274-278.

Alcoforado MJ, Nunes MF, Garcia R. 1999. A percepção da relação clima-saúde pública em Lisboa, no século XIX, através da obra de Marino Miguel Franzini. Revista Portuguesa de Saúde Pública 117(2): $31-40$

Almeida AD. 1817. Azeitonas maduras em Penafiel no fim de Abril do anno de 1817. Jornal de Coimbra $\mathbf{X}(\mathrm{LI})$ : 201-203, parte I, art. XIX.

Barriendos M. 1997. Climatic variations in the Iberian peninsula during the late Maunder minimum (AD 1675-1715): an analysis of data from rogation ceremonies. Holocene 7: 105-111.

Barriendos M. 2005. Climate and culture in Spain, religious responses to extreme climatic events in the Hispanic Kingdoms (16th-19th centuries). In Cultural Consequences of the Little Ice Age (Kulturelle Konsequenzen der Kleinen Eiszeit), Behringer W, Lehmann H, Pfister C (eds). Vandenhoeck \& Ruprecht: Göttingen; 31-86.

Barriendos M, Dannecker A. 1999. La sequía de 1812-1824 en la costa central catalana. Consideraciones climáticas e impacto social del evento. In La Climatología Española En los Albores del Siglo XXI, Raso JM, Martín Vide J (eds). Oikos-Tau: Barcelona; 53-62.

Barriendos M, Llasat MC. 2003. The case of the "Maldá" anomaly in the western mediterranean basin (AD 1760-1800): an example of a strong climatic variability. Climatic Change 61: 191-216.

Barriendos M, Gómez B, Peña JC. 1997. Old series of meteorologica readings for Madrid and Barcelona (1780-1860). Documentary and observed characteristics. In Advances in Historical Climatology in Spain, Martín Vide J (ed.). Oikos-Tau: Barcelona; 157-172.

Barriendos M, Martín-Vide J, Peña JC, Rodríguez R. 2002. Daily meteorological observations in Cádiz - San Fernando. Analysis of the documentary sources and the instrumental data content (1786-1996). Climatic Change 53: 151-170.

Bergström H, Moberg A. 2002. Daily air temperature and pressure series for Uppsala (1722-1998). Climatic Change 53: 213-252.

Bourke A. 1984. Impact of climatic fluctuations on European agriculture. In The Climate of Europe: Past, Present and Future, Flohn H, Fantechi R (eds). Reidel Publishing Company: Dordrecht, Boston, MA, Lancaster, PA; 269-314.

Bradley RS. 1988. The explosive volcanic eruption signal in northern hemisphere continental temperature records. Climatic Change $\mathbf{1 2}$ 221-243.

Bradley RS, Jones PD. 1995. Records of explosive volcanic eruptions over the last 500 years. In Climate Since AD 1500, Bradley RS, Jones PD (eds). Routledge: London; 606-622.

Briffa KR, Jones PD. 1992. The climate of Europe during the 1810s with special reference to 1816 . In The Year without a Summer? World Climate in 1816, Harington CR (ed.). Canadian Museum of Nature: Ottawa, ON.

Briffa KR, Schweingruber FH. 1995. Recent dendroclimatological evidence of northern and central European summer temperatures. In Climate Since AD 1500, Bradley RS, Jones PD (eds). Routledge: London; 366-392.

Briffa KR, Osborn TJ, Schweingruber FH. 2004. Large-scale temperature inferences from tree rings: a review. Global and Planetary Change 40: 11-26, DOI: 10.1016/S0921-8181(03)00095-X.

Briffa KR, Jones PD, Schweingruber FH, Osborn TJ. 1998. Influence of volcanic eruptions on Northern Hemisphere Summer temperature over the Past 600 Years. Nature 393: 450-455.

Briffa KR, Osborn TJ, Schweingruber FH, Harris IC, Jones PD, Shiyatov SG, Vaganov EA. 2001. Low-frequency temperature variations from a northern tree-ring-density network. Journal of Geophysical Research-Atmospheres 106: 2929-2941.

Brönnimann S. 2003. Picturing climate change. Climatic Research 22: 87-95.

Brunet M, Saladié O, Jones P, Sigró J, Aguilar E, Moberg A, Walther A, Lister D, López D, Almarza C. 2006. The development of a new daily adjusted temperature dataset for Spain (1850-2003).
International Journal of Climatology 26: 1777-1802, DOI: $10.1002 /$ joc. 1338

Bruzek V. 1992. Major volcanic eruptions in the nineteenth and twentieth centuries and temperatures in Central Europe. In The Year without a Summer? World Climate in 1816, Harington CR (ed.). Canadian Museum of Nature: Ottawa, ON.

Büntgen U, Frank DC, Nievergelt D, Esper J. 2006. Alpine summer temperature variations, AD 755-2004. Journal of Climate 19: 5606-5623.

Büntgen U, Frank DC, Grudd H, Esper J. 2008. Eight centuries of Pyrenees summer temperatures from tree-ring density. Climate Dynamics (in press). DOI: 10.1007/s00382-008-0390-x.

Camuffo D. 2002. History of the long series of the air temperature in Padova (1725-today). Climatic Change 53: 7-75.

Chaves JN. 1817. Conta de José Nunes Chaves, Médico em Villa-nova de Portimão no Reino do Algarve, pertencente aos annos de 1815 e 1816. Jornal de Coimbra $\mathbf{X}(\mathrm{L})$ : 128, parte I, art. VII.

Chenoweth M. 2001. Two major volcanic cooling episodes derived from global marine air temperatures. Geophysical Research Letters 28: 2963-2966.

Chuine I, Yiou P, Viovy N, Seguin B, Daux V, Le Roy Ladurie E. 2004. Grape ripening as a past climate indicator. Nature 432: 289-290.

Cook ER, D’Arrigo RD, Mann ME. 2002. A Well-Verified, MultiProxy Reconstruction of the Winter North Atlantic Oscillation Since AD 1400. Journal of Climate 15: 1754-1765.

Diodato N. 2007. Climatic fluctuations in southern Italy since the 17th century: reconstruction with precipitation records at Benevento. Climatic Change 80: 411-431.

Durão JJ. 1817. Extracto da Conta de José Joaquim Durão, Médico dos Partidos da Câmara, Hospital Civil, e Expostos, da Villa de Torres Vedras, pertencente ao anno de 1816. Jornal de Coimbra X(LI): 204, Parte I, art. XX

Fischer EM, Luterbacher J, Zorita E, Tett SFB, Casty C, Wanner H. 2007. European climate response to tropical volcanic eruptions over the last half millennium. Geophysical Research Letters 34: L05707, DOI :10.1029/2006GL027992.

Franzini MM. 1817. Observações Meteorologicas feitas na cidade de Lisboa no anno de 1816, e 1817, acompanhadas de varias reflexões sobre o estudo e applicação de Metéorologia, offerecidas á Real Academia das Sciencias. História e Memórias da Academia Real das Sciencias de Lisboa V(I): 92-125.

García R, Macías A, Gallego D, Hernández E, Gimeno L, Ribera P. 2003. Reconstruction of the precipitation in the Canary Islands for the period 1595-1836. Bulletin of the American Meteorological Society 84: 1037-1039.

Glueck MF, Stockton CW. 2001. Reconstruction of the North Atlantic Oscillation, 1429-1983. International Journal of Climatology 21: $1453-1465$

Gonzalez-Rouco JF, Heyen H, Zorita E, Valero F. 2000. Agreement between observed rainfall trends and climate change simulations in Southern Europe. Journal of Climate 13: 3057-3065.

Guiot J, Nicault A, Rathgeber C, Edouard J, Guibal F, Pichard G, Till C. 2005. Last-millennium summer-temperature variations in western Europe based on proxy data. Holocene 15: 489-500.

Harington CD. 1992. The Year without a Summer: World Climate in 1816. Canadian Museum of Nature, 576.

Hoyt DV, Schatten KH. 1998. Group Sunspot Numbers: A New Solar Activity Reconstruction. Solar Physics 179: 189-219, Reprinted with figures in Solar Physics 181: 491-512.

Jones PD, Davies TD, Lister DH, Slonosky V, Jónsson T, Bärring L, Jönsson P, Maheras P, Kolyva-Machera F, Barriendos M, MartinVide J, Alcoforado MJ, Wanner H, Luterbacher J, Rickli R, Pfister C, Schüpbach E, Kaas E, Schmith T, Jacobiet J, Beck C. 1999. Monthly mean pressure reconstructions for Europe 1780-1995 period. International Journal of Climatology 19: 347-364.

Lamb HH. 1970. Volcanic dust in the atmosphere with a chronology and assessment of its meteorological significance. Philosophical Transactions of the Royal Society of London. Series A: Mathematical and Physical Sciences 266: 425-533.

Lamb HH. 1995. Climate, History and the Modern World. Routledge: London; 433

Lean J, Beer J, Bradley R. 1995. Reconstruction of solar irradiance since 1610: Implications for climate change. Geophysical Research Letters 22: 3195-3198, DOI: 10.1029/95GL03093.

Le Roy Ladurie E. 2004. Histoire Humaine et Comparée du Climate. Canicules et Glaciers XIIIème-XVIIIème siècles. Editions Fayard: France; 726. 
Le Roy Ladurie E. 2005. Canicule, fraîcheurs, vendages (France, $\mathrm{XV}^{\mathrm{e}}-\mathrm{XIX}^{\mathrm{e}}$ siècles). Comptes Rendus Biologies 328: 213-218.

Le Roy Ladurie E, Daux V, Luterbacher J. 2006. Le climat de Bourgogne et d'ailleurs XIVe-XXe siècle. Histoire Economie Societé 3: $421-436$.

Luterbacher J, Schmutz C, Gyalistras D, Xoplaki E, Wanner H. 1999. Reconstruction of monthly NAO and EU indices back to 1675 . Geophysical Research Letters 26: 2745-2748.

Luterbacher J, Dietrich D, Xoplaki E, Grosjean M, Wanner H. 2004. European seasonal and annual temperature variability, trends and extremes since 1500 A.D. Science 303: 1499-1503.

Luterbacher J, Xoplaki E, Dietrich D, Rickli R, Jacobeit J, Beck C, Gyalistras D, Schmutz C, Wanner H. 2002. Reconstruction of sea level pressure fields over the eastern north Atlantic and Europe back to 1500. Climate Dynamics 18: 545-561.

Luterbacher J, Xoplaki E, Casty C, Wanner H, Pauling A, Küttel M, Rutishauser T, Brönnimann S, Fischer E, Fleitmann D, GonzalezRouco FJ, Garcia-Herrera R, Barriendos M, Rodrigo FS, GonzalezHidalgo JC, Saz MA, Gimeno L, Ribera P, Brunet M, Paeth $\mathrm{H}$, Rimbu N, Felis T, Jacobeit J, Dünkeloh A, Zorita E, Guiot J, Türkes M, Alcoforado MJ, Trigo R, Wheeler D, Tett S, Mann ME, Touchan R, Shindell DT, Silenzi S, Montagna P, Camuffo D, Mariotti A, Nanni T, Brunetti M, Maugeri M, Zerefos CS, De Zolt S, Lionello P, Rath V, Beltrami H, Garnier E, Le Roy Ladurie E. 2006. Mediterranean Climate Variability Over the Last Centuries: a review. In The Mediterranean Climate: an Overview of the Main Characteristics and Issues. Lionello P, MalanotteRizzoli P, Boscolo R (eds.). Elsevier, Amsterdam: The Netherlands, 27-148.

Mann ME. 2002. Large-scale climate variability and connections with the middle East in past centuries. Climatic Change 55: 287-314

Mann ME, Bradley RS, Hughes MK. 1998. Global-scale temperature patterns and climate forcing over the past six centuries. Nature 392: 779-787.

Mann ME, Gille E, Bradley RS, Hughes MK, Overpeck JT, Keimig FT, Gross W. 2000. Global temperature patterns in past centuries: an interactive presentation. Earth Interactions 4: 1-29.

Marques J. 2002. Estados do tempo e outros fenómenos, na região de Braga, no século XVIII. Bracara Augusta. Revista Cultural da Câmara Municipal de Braga. L: 97-194.

Martín-Vide J, Barriendos M. 1995. The use of rogation ceremony records in climatic reconstruction: a case study from Catalonia (Spain). Climatic Change 30: 201-221.

Maugeri M, Buffoni L, Chlistovsky F. 2002. Daily Milan temperature and pressure series (1763-1998): history of the observations and data and metadata recovery. Climatic Change 53: 101-117.

Meier N, Rutishauser T, Pfister C, Wanner H, Luterbacher J. 2007. Grape harvest dates as a proxy for Swiss April to August temperature reconstructions back to AD 1480. Geophysical Research Letters 34: L20705, DOI: 10.1029/2007GL031381.

Menzel A. 2005. A 500 year pheno-climatological view on the 2003 heatwave in Europe assessed by grape harvest dates. Meteorologische Zeitschrift 14: 75-77.

Oppenheimer C. 2003. Climatic, environmental and human consequences of the largest known historic eruption: Tambora volcano (Indonesia) 1815. Progress in Physical Geography 27: 230-259.

Osborn TJ. 1997. Areal and point precipitation intensity changes: Implications for the application of climate models. Geophysical Research Letters 22: 2829-2832.

Pauling A, Luterbacher J, Casty C, Wanner H. 2006. 500 years of gridded high-resolution precipitation reconstructions over Europe and the connection to large-scale circulation. Climate Dynamics 26: 387-405, DOI 10.1007/s00382-005-0090-8.

Pfister C. 1995. Monthly temperature and precipitation in Central Europe 1525-1979: quantifying documentary evidence on weather and its effects. In Climate Since AD 1500, Bradley RS, Jones PD (eds). Routledge: London; 118-142.

Piervitali E, Conte M, Colacino M. 1997. Summer air temperature anomalies in Europe during the century 1811-1910. Il Nuovo Cimento C 20: 195-208.

Písek J, Brázdil R. 2006. Responses of large volcanic eruptions in the instrumental and documentary climatic data over Central Europe. International Journal of Climatology 26: 439-459.

Post JD. 1970. The economic crisis of 1816-1817 and its social and political consequences. Journal of Economic History 30(1): $248-250$

Prohom MJ, Esteban P, Martín-Vide J. 2003. Surface atmospheric circulation over Europe following major tropical volcanic eruptions,
1780-1995. In Volcanism and the Earth's Atmosphere, Geophysical Monograph Series 139, Robock A, Oppenheimer C (eds). American Geophysical Union (AGU): Washington; 273-281.

Prohom MJ, Bradley RS. 2002. Anomalías de la precipitación invernal en la Península Ibñerica y Baleares después de grandes erupciones volcánicas tropicales (1901-1996). In El Agua y el Clima, En Guijarro JA, Grimalt M, Laita M, Alonso S (eds). Publicaciones de la Asociación Española de Climatología (AEC): Serie A, ${ }^{\circ} 3$, Marratxí (Mallorca); 521-532.

Robock A. 1994. Review of year without a summer? World climate in 1816. Climatic Change 26: 105-108.

Robock A. 2000. Volcanic eruptions and climate. Reviews of Geophysics 38: 191-219.

Robock A. 2005. Cooling following large volcanic eruptions corrected for the effect of diffuse radiation on tree rings. Geophysical Research Letters 32: L06702, Doi:10.1029/2004GL022116.

Robock A, Oppenheimer C (eds). 2003. Volcanism and the Earth's Atmosphere, Geophysical Monograph 139. American Geophysical Union: Washington, DC; 360.

Rodrigo FS. 2002. Changes in climate variability and seasonal rainfall extremes: a case study from San Fernando (Spain), 1821-2000. Theoretical and Applied Climatology 72: 193-207.

Rodrigo FS, Pozo-Vázquez D, Esteban-Parra MJ, Castro-Díez Y. 2001. A reconstruction of the winter North Atlantic Oscillation index back to AD 1501 using documentary data in southern Spain. Journal of Geophysical Research Atmospheres 106: 14805-14818.

Rodríguez R, Barriendos M, Jones PD, Martin-Vide J, Peña JC. 2001. Long pressure series for Barcelona (Spain). Daily reconstruction and monthly homogenization. International Journal of Climatology 21 1693-1704.

Rodríguez-Puebla C, Encinas AH, Nieto S, Garmendía J. 1998. Spatial and temporal patterns of annual precipitation variability over the Iberian Peninsula. International Journal of Climatology 18: 299-316

Sear CB, Kelly PM, Jones PD, Goodess CM. 1987. Global surface temperature response to major volcanic eruptions. Nature 330: $365-367$.

Serrano A, García JA, Mateos VL, Cancillo ML, Garrido J. 1999. Monthly modes of variation of precipitation over the Iberian Peninsula. Journal of Climate 12: 2894-2919.

Sigurdsson HS, Carey S. 1992. The eruption of Tambora in 1815 Environmental effects and eruption dynamics. In The Year without a Summer? World Climate in 1816, Harington CR (ed.). Canadian Museum of Nature: Ottawa, ON.

Simkin T, Siebert L. 1994. Volcanoes of the World: An Illustrated Catalogue of Holocene Volcanoes and their Eruptions. Smithsonian Institution, Geoscience Press: Tucson, AZ, updated online at http://www.volcano.si.edu/world/.

Slonosky VC, Jones PD, Davies TD. 2001. Atmospheric circulation and surface temperature in Europe from the 18th century to 1995. International Journal of Climatology 21: 63-75.

Stendel M, Mogensen IA, Christensen JH. 2005. Influence of various forcings on global climate in historical times using a coupled atmosphere-ocean general circulation model. Climate Dynamics 26: 1-15, DOI. 10.1007/s00382-005-0041-4.

Stommel H, Stommel E. 1983. Volcano Weather: The Story of 1816 , The Year without a Summer. Seven Seas Press: Newport, RI.

Stothers RB. 1984. The great Tambora eruption in 1815 and its aftermath. Science 224: 1191-1198.

Stothers RB. 1999. Volcanic dry fogs, climate cooling and plague pandemics in Europe and the middle east. Climatic Change 42: $713-723$.

Taborda JP, Alcoforado MJ, García JC. 2004. O clima do sul de Portugal no século XVIII. Centro de Estudos Geográficos: Lisboa.

Trigo RM, DaCamara C. 2000. Circulation Weather Types and their impact on the precipitation regime in Portugal. International Journal of Climatology 20: 1559-1581.

Trigo RM, Palutikof JP. 2001. Precipitation scenarios over Iberia: a comparison between direct GCM output and different downscaling techniques. Journal of Climate 14: 4422-4446.

Trigo RM, Osborn TJ, Corte-Real JM. 2002. The North Atlantic Oscillation influence on Europe: climate impacts and associated physical mechanisms. Climate Research 20: 9-17.

Trigo RM, Pozo-Vázquez D, Osborn TJ, Castro-Díez Y, GámisFortis S, Esteban-Parra MJ. 2004. North Atlantic Oscillation influence on precipitation, river flow and water resources in the Iberian Peninsula. International Journal of Climatology 24: 925-944. 
Vaquero JM. 2007. Historical sunspot observations: a review. Advances in Space Research 40: 929-941.

Vaquero JM, Trigo RM. 2005. Auroras observed in Portugal in late 18 th century obtained from printed and manuscript meteorological observations. Solar Physics 231: 157-166.

Vinther BM, Andersen KK, Hansen AW, Schmith T, Jones PD. 2003. Improving the Gibraltar/Reyjavik NAO Index. Geophysical Research Letters 30: 2222, DOI: 10.1029/2003GL018220.

Vupputuri RKR. 1992. The Tambora eruption in 1815 provides a test on possible global climatic and chemical perturbations in the past. Natural Hazards 5: 1-16.

Wagner S, Zorita E. 2005. The influence of volcanic, solar and CO2 forcing on the temperatures in the Dalton Minimum (1790-1830): a model study. Climate Dynamics 25: 205-218.

Webb P. 2002. Emergency relief during Europe's Famine of 1817 anticipated crisis-response Mechanisms of Today. Journal of Nutrition 132: 2092S-2095S.
Xoplaki E, Maheras P, Luterbacher J. 2001. Variability of climate in meridional balkans during the periods $1675-1715$ and 1780-1830 and its impact on human life. Climatic Change 48: 581-615.

Xoplaki E, Luterbacher J, Paeth H, Dietrich D, Steiner N, Grosjean M, Wanner H. 2005. European spring and autumn temperature variability and change of extremes over the last half millennium. Geophysical Research Letters 32: L15713, DOI:10.1029/2005GL023424.

Yoshimori M, Stocker TF, Raible C, Renold M. 2005. Externally forced and internal variability in ensemble climate simulations of the maunder minimum. Journal of Climate 18: 4253-4270.

Zerefos CS, Gerogiannis VT, Balis D, Zerefos SC, Kazantzidis A. 2007. Atmospheric effects of volcanic eruptions as seen by famous artists and depicted in their paintings. Atmospheric Chemistry and Physics 7: 4027-4042. 